\title{
The Contrastive Analysis of Chinese and English Tautologies under the Perspective of Construction Grammar
}

\author{
Hongjuan Fang \\ (Foreign Languages School, Zaozhuang University, Zaozhuang Shandong, 277160) \\ ahu0717@163.com
}

\section{Keywords: Tautology; Contrast; Construction Grammar; Pragmatic Meaning}

\begin{abstract}
The study on tautology has become an interesting and hot topic at home and abroad. The contrastive analysis on English and Chinese tautology from the perspective of Construction Grammar is still not sufficient, while the contrastive analysis is still necessary. This paper aims to contrast English and Chinese tautological construction in terms of structure and framework. This paper reveals that English and Chinese tautologies have a lot in common in terms of their skeletal structure and basic constructional meaning. Contrasted with English tautological construction, the Chinese counterpart is more flexible in structure, richer in pragmatic function, and has more constructional extensions. This analysis will contribute a lot to the understanding of the constructional inheritance mechanisms and the cognitive motivations of construction extension.
\end{abstract}

\section{Introduction}

Tautology is a characteristic and pervasive structure in English and Chinese conversations and literary works. Zhang Gong (1963: 169-170)[1] defines tautology as "a kind of judgement structure in which the subject and the predicative is expressed by the same words or phrases". The basic structure is “ $X_{1}$ BE $X_{2}$ " $\left(X_{1}+S H I\right.$ (是) $+X_{2}$ in Chinese), “ $X_{1} B E X_{2}, Y_{1}$ BE $Y_{2}$ " $\left(X_{1}+S H I\right.$ (是) + $\mathrm{X}_{2}, \mathrm{Y}_{1}+\mathrm{SHI}$ (是) $+\mathrm{Y}_{2},\left(\mathrm{Z}_{1}+\mathrm{SHI}\right.$ (是) $\left.+\mathrm{Z}_{2} \ldots\right)$ in Chinese), for example, war is war、boys will be boys, 专家就是专家 (experts are experts), 丁是丁, 卯是卯 (Ding is ding, mao is mao) etc. Tautology can be found in lots of languages, such as English, Chinese, French, Russian, Japanese and so on.

This paper takes the Construction Grammar theories as the guiding theory, tries to contrast the tautological constructions in Chinese and English. The corpora and relevant expressions in this paper are extracted from BNCweb corpus, CCL corpus conducted by Peking University, some are selected from Chinese literary works or works of relevant previous research.

\section{Literature Review}

\section{Literature Review of Researches Abroad}

Three main approaches adopted by scholars abroad could be of particular representatives: the radical Pragmatic Circle, with the study of Levinson (1983)[2]; the radical Semantic Circle, with the research of Wierzbicka (1987)[3] as the leading scholar, and the Middle Circle, with the work of Fraser (1988)[4] as the representative.

The Pragmatic Circle claims that the research of tautology should take its pragmatic inference as the focus. This circle proposes to reduce to a negligible amount the semantic contribution of a tautological construction, thereby pushing the burden of utterance interpretation almost entirely onto pragmatic inference. The importance of contextual information in the semantic interpretation of tautology is one of the research focus in this circle.

The Semantic Circle holds that the semantic meaning of tautological constructions could be solely inferred by the pragmatic inference. For example, Wierzbicka (1987)[3] states that each English tautological sentence would carry a unique and significant semantic contribution. So, the usual, universal and uniform pragmatic criterions could not provide the uniqueness and the specific meanings of each tautological constructions. 
Different from the above two circles, which choose one position and abandon another, the Middle Circle chooses a middle line. It claims that the semantic and pragmatic contributions should both be emphasized in the study of tautological constructions, which is exemplified in the research of Fraser (1988)[4], Farghal (1992)[5], Okamoto(1993)[6]. The Middle circle proposes that the understanding of tautologies relies on both semantic analysis and pragmatic inference. So, the position of this circle is relatively less radical. The problem of this circle is that, they pay less attention to the cognitive mechanisms of the semantic interpretations of tautologies.

\section{Literature Review of Domestic Tautology Research}

Domestically, there are mainly two approaches to the study of tautological constructions: the descriptive research and the explanative study. The descriptive research of tautological structures focus on the descriptions of their formal structures and the conclusion of their rhetorical effects (such as Shao Jingmin1986[7] etc.). Some scholars (with Gao Mingle2002[8] as the representatives) conduct research on the contrast of Chinese tautological constructions and the English counterparts, but these scholars only focus on the contrast of just one dimension, such as the contrast of their semantic features, or that of their formal structures. In their contrast of Chinese and English tautological constructions. In recent years, tautologies expressions have been drawing more and more attentions of Chinese researchers. They try to carry out some more insightful and complementary research of tautological constructions under the theoretical guidance of prototype theory (Gao Hang \& Zhangfeng 2000 [9]), within the relevance theory (Wen Xu 2003 [10], Chen Xinren 2004 [11]), from a multidimensional approach based on Conceptual Metonymy theory (Ma Wen \& Fan Zhenqiang 2007[12]), in light of the linguistic de-categorization theory (Liu Zhengguang 2005[13]), meaning and reference theory (Fan Zhenqiang 2014[14]) and within the theory of Construction Grammar. (Gao Hang 2010 [15], Fan Zhenqiang 2015 [16], Shao Jingmin 2015 [17] etc.) The above researches provide us with contributes a lot to the understanding of the mechanisms of tautologies' particular semantic characteristics and pragmatic functions. Despite that, further research is necessary to prove the feasibility, validity and the explanative power of the above study. Considering the above factors, this paper strives to make a contrastive study of Chinese and English tautological constructions in terms of their formal structure, semantic meaning and pragmatic function.

\section{Basic Assumptions of Construction Grammar}

The contrast of tautological constructions under the theory of Construction Grammar is relatively scarce. While the contrast of tautological constructions under Construction Grammar is necessary and critical, as this theory provides us with some relatively integral insights.

Construction Grammar holds that constructions are conventional pairings of form and function. (Goldberg 1995, 2006) From this perspective, we hold that tautological constructions are constructions, in which the formal structure, semantic meaning and the pragmatic function are conventionalized and entrenched. Construction Grammar leads us to a new direction, that is, the contrast of Chinese and English tautological constructions should take the contrasts of their formal structure, semantic meaning, and discourse functions as an integrated whole.

While there are lots of similarities and differences in terms of their formal structure, semantic meaning and pragmatic functions, we believe that a contrastive study of Chinese and English tautological constructions under the guidance of Construction Grammar is necessary and complementary to previous research. This research is also significant for a more systematic and deeper understanding of Chinese and English tautological constructions.

\section{Contrastive Analysis of Chinese and English Tautological Constructions}

\section{The Contrast of the Formal Framework}

The Formal and Structural Analysis of Chinese Tautological Constructions

According to our corpus retrieval and the findings of the previous research, this paper finds some similarities and differences of Chinese and English tautological constructions. First, according to 
their general formal framework, we claim that Chinese tautological constructions could be classified into 2 categories, whose patterns could be represented as: (1) $X_{1}+S H I$ (是) $+X_{2}$, the other as (2) $\mathrm{X}_{1}+\mathrm{SHI}$ (是) $+\mathrm{X}_{2}, \mathrm{Y}_{1}+\mathrm{SHI}$ (是) $+\mathrm{Y}_{2},\left(\mathrm{Z}_{1}+\mathrm{SHI}\right.$ (是) $\left.+\mathrm{Z}_{2} \ldots\right)$.

$\boldsymbol{X I}+\boldsymbol{S H I}$ (是) $+\boldsymbol{X}_{2}$ : this construction is composed of only one nominal or verbal phrase, which is presented as $X_{1}$ and $X_{2}$, in which $X_{1}$ and $X_{2}$ are the same nominal phrase. for example:

（1）事实是事实, 想象只是一种奢侈。(老舍《牛天赐传》)

（2）你干嘛气成这样啊? 皇上是皇上啊。(《还珠格格》第二部)

（3）美国兵是美国兵，可不象头回那么威风了。(《杨朔《三千里江山》)

（4）祥子到底是祥子, 祥子拼命跑, 还是没有别人的份儿。(老舍《骆驼祥子》)

From the above examples, we find that the connective "SHI (是)" can be modified by some adverbs. The modifying phrases are conducive to the enhance the emphasizing effects. The above adverbs or modifying phrases are always frequently adopted: “就”, “总”, “总归”, “终归”, “到 底”, “终究”, “终竟”, “毕竟”, “究竟”, “必定” etc., with their meaning equivalent to just, always, all in all, at last, surely, after all etc. For example:

(5) 唉，女人究竟是女人。(曹禺《雷雨》)

（6）不懂就是不懂, 不要装懂。(毛泽东《论人民民主专政》)

（7）不管她信不信, 事实总是事实。(赵树理《田寡妇看瓜》)

（8）两块钱到底是两块钱, 他盘算着。(老舍《骆驼祥子》)

$\mathrm{X}_{1}+\mathrm{SHI}$ (是) $+\mathrm{X}_{2}, \mathbf{Y}_{1}+\mathrm{SHI}$ (是) $+\mathrm{Y}_{2},\left(\mathrm{Z}_{1}+\mathrm{SHI}\right.$ (是) $+\mathrm{Z}_{2} \ldots$ ): in this sub-category, at least two $X_{1}+S H I$ (是) $+X_{2}$ structures are employed in this structure. In each structure, the same phrase are repeated both in the subject position and the predicate position. Illustrations are the following:

（9） 往年是往年，今年是今年，你当年年一个样。(周立波:《暴风骤雨》)

（10） 诸位放心, 从此, 她是她, 我是我, 再也不吵嘴。(老舍《骆驼祥子》)

(11) 一是一，二是二。丁是丁，卯是卯。

（12）我决不能让三禁半途而废。一是一, 二是二。葫芦是葫芦, 漂是漂。如果害怕牵 一发动全身, 我们便什么事也干不了。(胡辛《蒋经国与章亚若之恋》)

We find double nominal phrase tautological construction, represented as $\mathrm{X}_{1}+\mathrm{SHI}$ (是) $+\mathrm{X}_{2}, \mathrm{Y}_{1}$ $+\mathrm{SHI}$ (是) $+\mathrm{Y}_{2}$, as is shown by 往年是往年, 今年是今年 in example (9), and 她是她, 我是我 in example (10). We find double $X_{1}+$ 是 $+X_{2}, Y_{1}+$ 是 $+Y_{2}$ expressions, illustrated by 一是一, 二是二。丁是丁, 卯是卯 in example (11), and “一是一, 二是二。葫芦是葫芦, 漂是漂。” in example (12). We may conclude that Chinese tautological constructions are more flexible and Chinese are more inclined to use successive tautological expressions.

The Formal and Structural Features and Categories of English Tautological Constructions

$\mathrm{X} 1+\mathrm{BE}+\mathrm{X}_{2}$ : the formal structural features and categories of English tautological constructions are quite similar to that of Chinese tautological constructions. As is governed by English grammatical and other formal rules, English tautological constructions should conform to relevant rules in terms of their number, tense, gender and so on. Wierzbicka (1987)[3] holds that English tautological constructions with an $\mathrm{X} 1+\mathrm{BE}+\mathrm{X}_{2}$ form could be furtherly categorized into 3 categories:

a) $\mathrm{NP}_{\text {abstr }}+\mathrm{BE}+\mathrm{NP}_{\mathrm{abstr}}$ : in this category, the nominal phrase is always bare and no other modifying phrases are pre-posed. The nominal phrases occurring in this category are always abstract nominals. For example:

(13) Business is business.

(14) War is war.

(15) Politics is politics.

(16) Life is life.

As the examples (13-16) illustrates, the nominal phrases business, war, politics and life all have some abstract references.

b) $\mathrm{NP}_{\text {humpl }}+\mathrm{BE}+\mathrm{NP}_{\text {humpl }}$ : The nominal phrases in this category are always plural nouns with a 
reference of human beings. For example:

(17) Children are children. They are there to be put up with.

(18) Women are women.

(19) Boys are boys.

(20) The point I want to make is that racists are racists, with or without the exposure of genital mutilation. (BNCweb corpus)

As the examples illustrates, the nominal phrases such as children, women, boys, and racists are always plural in form, and refer to human beings in meaning.

From the corpora retrieved, we find that the nominal phrases occurring in this sub-category are not all NPs referring human beings. NPs referring to things are also occurring in this category, but no modifying phrases are pre-positioned. For example:

(21) Facts are facts.

(22) Truth is truth to the end of the reckoning.

(23) However, by-products are by-products, and we ought to concentrate on its intended use. (BNCweb corpus)

The examples (21-23) show that facts, truth and by-products are mass noun or plural noun. they have non-human references and no modifying phrases are identified before the subjects.

c) ${ }_{\text {art }} \mathrm{NP}+\mathrm{BE}+{ }_{\mathrm{art}} \mathrm{NP}$ : the nominal phrases in this sub-category are always in singular form, with certain articles before subjects.

(24) A deal is a deal. (BNCweb corpus)

(25) The law is the law. (BNCweb corpus)

(26) A promise is a promise. (BNCweb corpus)

(27) A rule is a rule. (BNCweb corpus)

Examples (24-27) show that the article-modifying and singular-form nouns such as deal, law, promise and rule show that the can appear in the ${ }_{\text {art }} \mathrm{NP}+\mathrm{BE}+{ }_{\text {art }} \mathrm{NP}$ sub-category.

$\mathrm{X}_{1}+\mathrm{BE}+\mathrm{X}_{2}, \mathrm{Y}_{1}+\mathrm{BE}+\mathrm{Y}_{2}$ : a majority of English tautological constructions are the $\mathrm{X}_{1}+\mathrm{BE}+$ $\mathrm{X}_{2}$ category, while a minority part is found to have a framework of $\mathrm{X}_{1}+\mathrm{BE}+\mathrm{X}_{2}$, and $\mathrm{Y}_{1}+\mathrm{BE}+\mathrm{Y}_{2}$. That is, two " $\mathrm{X}_{1}+\mathrm{BE}+\mathrm{X}_{2}$ " patterns are combined with and as the connectives. Generally speaking, this kind of structure is quite rare in English, whose productivity power is quite weak. (Wierzbicka 2003)[3] As the examples show:

(28) He knew his son was all mouth and trousers but fair is fair, and family is family. (BNCweb corpus)

(29) It is still wise to follow the rule: east is east and west is west. (BNCweb corpus)

(30) To Hurston, people are people and life is life, whether in New York or Port-au-Prince, whether black or white. (BNCweb corpus)

(31) Boys will be boys and girls will be girls.

Examples (28-31) illustrate two " $\mathrm{X}_{1}+\mathrm{BE}+\mathrm{X}_{2}$ " patterns can be combined, with and as the connectives, to form a whole new category, the personal attitudes and affections can be clearly inferred from the succession of two " $\mathrm{X}_{1}+\mathrm{BE}+\mathrm{X}_{2}$ " chunks.

According our corpus, structures with more than two chunks of " $\mathrm{X}_{1}+\mathrm{BE}+\mathrm{X}_{2}$ " are not found in English. So, structures with more than two chunks of " $\mathrm{X}_{1}+\mathrm{BE}+\mathrm{X}_{2}$ " is believed to be a particular pattern in Chinese.

According our corpora, in Chinese, a succession of negative " $\mathrm{X}_{1}+\mathrm{BE}+\mathrm{X}_{2}$ " chunks can also be combined to form a tautological construction. For example:

（32）陈白露是个什么东西, 舞女不是舞女, 娼妓不是娼妓, 姨太太不是姨太太, 这么 一个贱货! (曹禺《日出》)

（33） 你今天怎么回来就鼻子不是鼻子，眼睛不是眼睛?

Examples (32-33) provide us with illustrations of succession of negative " $\mathrm{X}_{1}+\mathrm{BE}+\mathrm{X}_{2}$ " chunks. This kind of tautology mainly convey a strong personal attitude and feelings through a succession of negative chunks. Similar idioms can be identified in Chinese, such as “土不土, 洋不洋”, “男不 男, 女不女” etc. The implied meanings of this kind of idioms are similar to the above tautologies. 
We should be clear that not all the “ $\mathrm{X}_{1}+\mathrm{SHI}$ (是) $+\mathrm{X}_{2}, \mathrm{Y}_{1}+\mathrm{SHI}$ (是) $+\mathrm{Y}_{2}$ ” constructions have got their negative forms.

The similar negative chunks of tautological constructions are not found in English according to our corpora obtained.

\section{The Contrast of the Repeated Parts}

In Chinese, the words and phrases that can occur in the tautological constructions are numerous. Besides nominal phrases, other phrases such as adjectives, verbs, adverbs, pronouns, numerical phrases, numbers, "DE" constructions, verb-object structures and numerical phrases etc. for example:

（34）东西好是好, 就是贵了点儿。(adjectives)

（35）买, 没有想想看, 连价钱也不还, 买就是买。(verbs)

（36）管它呢, 已经就是已经。(adverbs)

（37）诸位放心, 从此, 她是她, 我是我, 再也不吵嘴。(代词)

（38）一是一, 二是二; 四是四, 十是十。(数词)

（39）公家的就是公家的，私人的就是私人的。(“DE” structure)

(40) 逛街是逛街, 可是不买东西。(verb-object structure)

（41）两块钱到底是两块钱, 他盘算着。(numerical phrase)

（42）正式的场合毕竟是正式的场合，所以必须穿得整齐些。(nominal phrases)

Wierzbicka (1987)[3]'s classification of English tautological constructions only focus on the constructions with nominal phrases as the identical part. Without doubt, a majority of English tautological constructions have nominal phrases as their identical parts in the subject and predicative position. But that is not the absolute case. According our corpora, a minority of English tautological constructions have nominalized verbs and adjectives as the identical part in their construction. For example:

(43) Cheating is cheating.

(44) Enough is enough.

(45) White is white (and black is black.)

(46) Many dispense with such niceties, arguing that porn is porn however you look at it. (BNCweb corpus)

In the above examples, we have nominalized verbs such as cheating, adjective such as enough and porn.

\section{The Contrast of Verbs of Tautological Constructions}

From the examples above, we know that normally take have the judgement verb “是” as the verb connecting subjects and predicatives in Chinese tautological constructions. Besides that, in some cases, other verbs such as “像, 为, 归” etc. can also be adopted to be the judgement verbs in Chinese tautological constructions. As we have shown in the previous section, sometimes, the negative word “不” can be put before the judgement words. For example:

(47) 知之为知之, 不知为不知, 是知也。(孔丘《论语》)

（48）可是说归说, 做归做, 他又重蹈前三任的覆辙, 成为第四个栽倒者。

(49) 人不像人, 鬼不像鬼。

In the judgement verb's position, “为” in example (47), “归” in example (48), and negative verbs “不像” in example (49) are all found in Chinese tautological constructions,

Different from the Chinese counterparts, the variants of $B E$ appear in English tautological constructions. The difference is that the judgements verbs in Chinese tautological constructions have no tense variants, while the BE copular should conform to the contextual requirements and the tense rules of grammar. So, in English tautologies, we find will be in the copula position. For example:

(50) Boys will be boys and girls will be girls.

(51) Fools will be fools. 
We mentioned that Chinese judgement verbs such as “是” can be modified by some modifying phrases, such as verbs. Except that, Chinese usually don't have modifying phrases before the subject and predicative positions. While English tautological constructions sometimes take "all" as the modifying phrase for the subject. That is, in some English tautological constructions, we use all to modify subjects to cover all the members of the subjects' references. As examples (52-53) illustrates:

(52) All wizards are wizards. (BNCweb corpus)

(53) All mice are mice. (BNCweb corpus)

In the above examples, "all" is used to modify wizards and mice respectively, so as to emphasize that all the members of wizards and mice are supposed to have got the required attributes.

\section{Summary}

The contrastive analysis of Chinese and English tautological constructions from the perspective of Construction Grammar theory is necessary and complementary to previous research. Through our contrastive analysis of Chinese and English tautological expressions, we find that there are both similarities and differences. On the one hand, they are similar in their framework and structure. That is $X_{1}+$ 是 $(B E)+X_{2}$. On the other hand, they have some differences. In form, Chinese tautological constructions are more flexible. We can find more structures in Chinese. Two or more than two $X_{1}+$ $S H I$ (是) $+X_{2}$ are allowed in Chinese to express relevant pragmatic functions. When in English, there is only a small number of expressions composed of two $X_{1}+B E+X_{2}$. More than two $X_{1}+$ $B E+X_{2}$ chunks are not allowed in English tautological constructions.

While English tautologies can only express contrasts and distinctions besides the meaning of emphasizing and confirm typical attributes. The above conclusion is only obtained through our corpora in-hand. We will later go on to testify the validity of this paper with a bigger amount of corpus.

\section{Acknowledgements}

This work was s supported by grants from the Social Science Fund of Shandong Province Education Department (RW2018BBC058), the $2^{\text {nd }}$ Foreign Linguistics and Applied Linguistics Research Program of Guangdong University of Foreign Studies (002201611015), and the 2016-2017 Year Research Program of Shandong Provincial Education Sciences (YC2017100).

\section{References}

[1] Zhang Gong. Modern Chinese Rhetoric [M]. Tianjin: Tianjin People's Press, 1963: 272.

[2] Levin son Stephen-C. Pragmatics[M]. Cambridge: Cambridge University Press, 1983.

[3]Wierzbicka Anna. Boys Will Be Boys: 'Radical Semantics' vs. 'Radical Pragmatics'[J]. Language, 1987, (1): 95.

[4] Fraser Bruce. Motor oil is motor oil[J]. Journal of Pragmatics, 1988, (2): 215-220.

[5] Farghal M. Colloquial Jordanian Arabic Tautologies[J]. Journal of Pragmatics, 1992, (3): 223-240.

[6] Okamoto S. Nominal Repetitive Constructions in Japanese: the "tautology" Controversy Revisited. [J]. Journal of Pragmatics, 1993, (5): 433-466.

[7] Shao Jingmin. The Analysis of Tautologies [J]. Chinese Studies, 1986, (1): 13-19.

[8] Gao Mingle. The Contrast of Tautologies in Chinese and English [J]. Chinese Teaching in the World, 2002 (2) :43-46.

[9] Gao Hang, Zhang Feng. A Cognitive Account of Tautologies [J]. Journal of P LA University of Foreign Languages, 2000, (5): 27-31.

[10] Wen Xu. The Characteristic Analysis and Cognitive Account of Tautological utterances [J]. Foreign Languages and Literatures, 2003, (3): 29-33.

[11]Chen Xinren. A Pragmatic-cognitive Account of Epanadiplosis in English [J]. Foreign 
Languages Research, 2004, (1): 45-50, 80.

[12] Ma Wen, Fan Zhenqiang. A Multidimensional Approach to the Study of Nominal Tautologies [J]. Journal of Guizhou University (Social Sciences Edition), 2007, (1): 108-114.

[13] Liu Zhengguang. A Reexamination of the Tautological Construction in light of the Linguistic Decategorization Theory[J]. Modern Foreign Languages, 2005, (2): 5-15, 112.

[14]Fan Zhenqiang. The Dual Reference of Nominal Tautology and Its Realization: From Philosophy of Language to Embodiment [J]. Jianghan Academic, 2014, (5): 103-109.

[15] Gaohang. A Construction Grammar Analysis of Tautologies, [J]. Journal of P LA University of Foreign Languages, 2010, (5): 1-6, 127.

[16]Fan Zhenqiang. A Reexamination of the Interpretation of " $\mathrm{N}$ is $\mathrm{N}$ " tautologies from the perspective of Dynamic Category Construction [J]. Foreign Language Education, 2015, (4): 32-36.

[17] Shao Jingmin. On the Theories and Research Methods of Frame Constructions [J]. Chinese Studies, 2015, (2): 3-8. 